\title{
Sporting Gender: Women's Footballing Bodies As Sites/Sights for the (Re) Articulation of Sex, Gender, and Desire
}

\author{
Jayne Caudwell \\ Leeds Metropolitan University
}

\begin{abstract}
Past and present participation in the game of football (soccer) by women and girls in the UK is mostly through organizational structures and legal and discursive practices that differentiate players by sex and incidentally gender. In this article, the author argues that the emphasis on sex and gender differentiation in football underpins a sporting system that is unable to move beyond sex as pregiven and the sex/gender distinction. The author engages with feminist-queer theory to illustrate how sex, gender, and desire are regulated in order to uphold social relations of power. The focus on women's footballing bodies demonstrates how the sexed body is socially constructed to inform gender and sexuality. In addition, the author highlights resistance to the compulsory order woman-feminine-heterosexual and presents examples of rearticulations of sex-gender-desire.
\end{abstract}

Au Royaume-Uni, la participation passée et présente en soccer féminin est surtout le fait de structures organisationnelles et de pratiques discursives et légales qui différencient les joueurs selon leur sexe et, incidemment, leur genre. Dans cet article, l'auteur suggère que l'accent placé sur la différenciation de sexe et de genre en soccer sous-tend un système sportif qui ne peut dépasser la distinction sexe/genre ou le sexe, comme élément a priori. À partir de la théorie féministe et «queer», l'auteur illustre comment le sexe, le genre et le désir sont régulés de façon à soutenir les relations sociales de pouvoir. Le fait de se centrer sur le corps des joueuses démontre comment le corps sexué est construit socialement pour informer le genre et la sexualité. De plus, l'auteur mets l'accent sur la résistance au trio obligatoire femme-féminine-hétérosexuelle et présente des exemples de nouvelles expressions du sexegenre-désir.

This article explores the openings of a deconstruction of the compulsory order sex-gender-desire might offer sport feminists. (Here desire is used to indicate sexuality.) The discussions that follow question the usefulness of the sex/ gender distinction and offer an opening for a move beyond the idea that sex is "natural" and pregiven. A queer-feminist approach is taken to analyze practice that upholds the sporting system of sex-gender differentiation in football contexts in England and Wales.

First, I highlight and critique the ways social and discursive practices regulate and formulate "women's" sexed-gendered bodies. This involves an engagement with the body as a social construct and a focus on how sex-gender-desire are ordered. More specifically, I offer an exploration of the regulatory practices that

The author is with the School of Leisure and Sport Studies at Leeds Metropolitan University, Leeds, LS1 3HE, UK. 
serve to maintain and protect woman-feminine-heterosexual and privilege heterofemininity. Second, I consider sporting moments when women's footballing bodies provide possible sites/sights for the rearticulation of the compulsory order woman-feminine-heterosexual. Here, shifting and emerging gender-desire identities that challenge heterofemininity are significant. In addition, bodies that resist the sexed body binary offer sites/sights where we can begin to theorize and critique dimorphic sex.

In short, the aim of the article is to illuminate the operation of sport's sexgender power relations and illustrate resistance that disturbs current notions of sex-gender differentiation within football contexts. (For further discussion on the social place of football for women in England and Wales, see Caudwell, 2002.)

To date, there has been little theoretical critique of the sex/gender distinction in sport. Birrell and Cole (1990) have explored how sex difference is constructed in their account of Renee Richards, and they demonstrate how sport ideology produces a narrative that gives meaning to gender and notions of "naturalized" sex. However, there is a lack of critique of how sex is understood as pre-given and most sport founded on sexual differentiation. John Hood-Williams (1995) does provide an important account that first refutes the existence of a two-sex system and second critiques the International Olympic Committee's endeavors to sex athletes. He argues that using a binary system to classify athletes is "tautological and that there will never be a true sign of a true sex, whatever the hopes of the IOC" (p. 290). Such a critical approach rocks the very foundation and arrangement of competitive sport. This article also offers a move toward problematizing dimorphic sex.

\section{Methodology}

Specific research findings, as well as a broader engagement with practices that shape women's experiences of football, the sexed body, gender, and sexuality underpin the following discussion. The research findings, presented as quotations, are taken from qualitative questionnaire and interview research. Eight hundred and seventy questionnaires were sent out to all clubs registered in the Football Association (FA) women's regional league between October 1997 and March 1998. The questionnaire, accompanied by a letter explaining the research, was sent to the club secretary of all teams registered in the 10 regional leagues in England and Wales. (Scotland has its own league system.) The club secretary was asked to distribute the questionnaire to two players in the club. In this way, the sample was not random but represents only players competing in the regional league system (season 1997-98) and the decisions made by the club secretaries to give out the questionnaires and to whom. Four hundred seventy-three completed questionnaires were returned.

This preliminary research was followed by 14 in-depth semistructured interviews with women players between 21 and 42 years of age who played during the 1997-98 and 1998-99 seasons.

The decision to use postal questionnaires was based on the existing lack of large-scale, detailed information on women who play football in England and Wales. In accordance with the arguments put forward by feminist researchers Kelly, Burton, and Regan (1994), I felt it would be possible to design the questionnaire so that woman completing it would feel comfortable doing so. In particular, the disclosure of sexuality might have been easier because of the anonymity of the questionnaire. 
The questionnaire response rate (over 50\%) suggests it was successful in amassing a range of information. The results are mostly quantitative; however, the last question is an open question that inspired some qualitative findings. Since all but one of the questions are closed, the depth of inquiry the questionnaire seeks to achieve is debatable.

In designing the questionnaire, an introductory passage to contextualize the research was included. In this preamble, I position myself as a player aware of the significance of the game to women, whilst simultaneously acknowledging the general lack of literature on women players. By highlighting my "insider" status and move to acquire more information, I hoped the women would engage with the questionnaire because they were also interested in the research. This shared interest in the research topic has been described within feminist methodology as collaborative research. In many ways, it supports Reinharz's (1983) notion of "partnership of co-research." It is virtually impossible, however, to ascertain the extent to which the women engaged with the research and why they completed the questionnaires. Indeed, it would be foolhardy to assume all those involved in the research share the research interest. This response to the final question on the questionnaire offers an explicit example of the extent to which this participant did not engage with the issues presented in the questionnaire:

The FA are not interested and their investment in women's football is just for show. I also think that these kind of problems are much more important for academic study than whether women football players live up to pathetic stereotypes of working class, lesbians who drink beer and smoke tabs. Who cares about those issues - the football is important, not our class or sexuality.

The intention to explore the women's personal circumstances-for example, their experience as it relates to their socioeconomic status and sexuality-is met here with derision. This research participant registers her agenda as a focus on the governing body of the game. Clearly, we do not share the same research interest. That said, some women did make comments on the questionnaire or in an accompanying letter claiming that they were interested in the research and the findings, asking for help and advice in their own research (student dissertations), and offering a contact if I required further help and assistance. In total, 9 women volunteered to be of further assistance. Contact was made with 8 of the women. Two of these women were virtually impossible to meet with, as they lived too far away from my research base. Consequently, 6 of the 14 women who took part in the interviews engaged with the research via the questionnaires.

Returning to the questionnaire design, I aimed to transform the way particular questions have traditionally been asked. For example, as a lesbian, I often feel excluded by the existing definitions of relationship status. The categories single and married or Miss and Mrs. are frequently used as a way to describe heterosexual relationships and women's status in relation to men. As a way to omit this sexist and heterosexist language, the following categories were used in the questionnaire: not in a relationship, in a casual relationship, in a serious relationship, or in a serious and permanent relationship. Although the notion of "permanent" is problematic, the term was used because I wanted lesbians, without the privilege of recognition that goes with marriage, to be able to make visible their long-term relationships. By designing certain questions so as to be sensitive to the needs of 
different women-for example, lesbians, single mothers, and careers-the aim was not to exclude their "voices." The anonymous nature of the questionnaire also allowed the women to respond to the question, Would you describe yourself as: by choosing "heterosexual," "bisexual," "gay/lesbian," or "prefer not to answer," thus providing a terse representation of sexuality. Issues surrounding sexuality are picked up and explored more fully in the interview research.

Interviews can offer a unique insight into the meanings and significance of lives and lived experience. Feminists keen to explore in detail women's particular experiences have championed the interview as a method of inquiry. The accounts made available through interviewing can provide a rich source of research material. That said, the interview method as used within this project also has its limitations. The sample reflects a particular group of individual women; therefore, the interview material is not representative data, and the knowledge generated from the interviews is not universal. The sample of women is not random but selected by way of expressed interest in the research topic.

Aspects of the research can be considered sensitive-for example, issues surrounding sexuality. Gill Clarke (1997), during her work on lesbian PE teachers, adopted a snowballing technique as a way to make contact with women who felt able and willing to take part in the research. She later critiques this method because she found the women tended to be very similar - that is, her sample was made up of all White women and mostly middle class. Through snowballing, the women introduce other research participants to the researcher, and the new research participants tend to come from a similar socioeconomic background (Clarke, 1997).

For two reasons, I was keen to make contact with women who were interested in the research topic. First, I wanted to work with women as partners in research (Reinharz, 1983) and, second, I wanted to allow women to feel able and willing to discuss some of the sensitive aspects of the research topic. In addition, I wanted to avoid interviewing many women who share similar experiences with me as White and middle class. With this in mind, women who expressed an interest in the research were interviewed. These women first became apparent during the questionnaire stage of the research. (Now I wish that I had devised a specific question on the questionnaire asking for women volunteers!) In addition, there were women I knew of through my own involvement in the game who also expressed an interest in the research; therefore, the research participants were women who were keen to be involved in the research. This decision meant that the women were geographically dispersed and played at different levels and on different teams. As such, it is impossible to universalize their experiences and claim that they represent a particular group of footballers. The research material represents the specific situation facing each individual woman.

\section{The Body As a Social Construct}

This article aims to explore and document how women's bodies are sites/ sights for the [re] articulation of sex-gender-desire. Women's everyday experiences are offered as a way to illustrate the operation of social relations and the regulation of women's bodies in football contexts. In this vein the analysis is feminist. The engagement with feminist theory draws specifically on social construction theory.

Social construction theory posits that the body is "somehow shaped, constrained and even invented by society” (Shilling, 1993, p. 70). A range of social 
constructionist views exists. On the whole, feminist theorists favoring social construction are concerned with the ways women's and men's bodies are differently and unequally imbued with social meanings. More specifically, this article focuses on sex-gender-desire and women's sexed body as produced through practices implicit to sport's discourse. Such an approach can be described as feminist-queer.

Foucault (1975) positions the body entirely within the realm of the social. As such, the body does not exist as a biological entity; instead, the body is produced and controlled through a series of regulatory practices. These practices can be linked through the process of genealogy. That is, they have functioned and developed over a period of time; the body is not beyond history but is produced in and through history. Elizabeth Grosz (1994) suggests that "for Foucault, the body is penetrated by networks and regimes of power-knowledge that actively mark and produce it as such" (p. 122). The body therefore is the object of power's operations and becomes marked by power relations. Some feminists have made use of Foucault's analysis of embodiment, power, and knowledge as a way to rethink the stable identity “woman” (see, e.g., Bartky, 1988; Bordo, 1993; Butler, 1990; Gatens, 1992; McNay, 1992). By understanding how the body is signified and sexed as "woman," feminists are able to challenge the concept as a natural given.

For instance, Monique Wittig (1981) argues that the category "woman" is an imaginary formation. It is the corollary of a social relationship, in particular political, economic, and ideological relations. She refutes the physical aspects of the sexed body and positions "heterosexuality as the social system which produces the doctrine of the difference between the sexes to justify this oppression" (cited in Conboy et al., 1997, p. 317). In this way, her analysis reflects a feminist-Foucaultian approach by taking account of social relations and the process of categorizing the sexed body through marking sex. Interestingly, for Wittig, the lesbian body escapes sexual signification and challenges the assumption of the category "woman," because lesbians do not have a socially sanctioned relationship to men. Therefore, they do not exist within the same set of political and economic relations that heterosexual women do. This focus on lesbianism, as a way to challenge the marking of the sexed body, moves beyond a Foucaultian analysis in as much as it begins to conceptualize preinscribed or reinscribed bodies.

Judith Butler (1990, 1993) also develops some of Foucault's theoretical concepts. She supports the idea that sex and sexual difference are not pregiven but produced and materialized through time and discourse. She goes on to argue that the sexed body is presented as stable and fixed; however, she reminds us that this process is in fact incomplete: "Bodies never quite comply with the norms by which their materialization is impelled" (1993, p. 2). Hence, there exists instability. Such an insight opens the way for a consideration of "possibilities for rematerialization" and the prospect of "spawn[ing] rearticulations" (1993, p. 2). In particular, she considers abject bodies or those bodies that are unable or do not cite an inscription. Wittig's "lesbian body" and Butler's "abject bodies" offer ways to move beyond the impasse left by Foucault's notion of "docile bodies." Foucault argued that bodies passively receive and accept signification. He failed to consider in detail bodies that avoid and/or ignore inscription, thus making it difficult to theorize corporeal challenges to the heterosexual gender imperative.

It is these debates within the field of social theory and the body that inform the discussions that follow. In particular, a Butlerian approach is relied on to make 
sense of the women's experiences of football as well as sex, gender, and desire. Through such an approach, I offer a feminist-queer analysis and, by its very nature, this cannot be viewed as an absolute, universal account.

\section{Regulating and Ordering Sex, Gender, and Desire in Football Contexts}

Some time ago, Susan Bordo (1993) argued that it is the body that functions as a site for the reproduction of femininity. Even earlier, Sandra Bartky (1988) identified three disciplinary practices that produce the body as recognizably feminine. In brief, these are practices that regulate body size, the use of the body as an ornamental surface, and the bodily display of a repertoire of appropriate gestures and postures. Both writers position the body as central to any discussion of gender and sexuality and expose femininity as an artifice that is regulated via social and discursive practice. Moira Gatens (1992) argues that these mechanisms, through which the body is invested, result in indicators of sexual difference, namely the embodiment of femininity and masculinity. It is this materialization (embodied gender "norms") of sex difference that propels gendered power relations. In short, feminists identify the "legible" body, the body that is recognized and understood as "woman," as socially constructed by power relations to uphold and continue to drive social relations to power.

In this article, I borrow from Butler (1990) and illustrate the "compulsory order of sex-gender-desire" as it exists in football contexts. A theme that emerged powerfully from the research was women's awareness of embodiment, and their location on a sex-gender-desire landscape. In other words, players are particularly aware of their embodied identity as "woman" (to be read as heterosexual and feminine). The findings illustrate how "woman" is constructed and given through social and discursive practices and highlight the operation of the compulsory order of woman-feminine-heterosexual. It is clear that the body provides a site/sight for anchoring the lineage. Being read as a "woman" who plays football requires compliance with production of corporeality as it relates to sex-gender-desire "norms" and "ideals."

The women's accounts suggest that gendered and sexual stereotypes abound, giving another presumed order woman-masculine-lesbian or, as Halberstam (1998) argues, a normative and reclaimed order in her accounts of "female masculinity," currency within this specific sporting context. However, the adoption of a masculine style is problematic. It is this that I focus on initially to demonstrate how women's footballing bodies are disciplined by the woman-feminine-heterosexual imperative that supports sport's system of sex-gender differentiation.

I argue that regulation and ordering operate within the confines of hegemonic heterosexuality. From the research, it emerges that desire (sexuality) informs gender (and vice versa), and gender informs sex (and vice versa). In fact, the three are inextricably linked. For women who play, to be read as mannish, nonfeminine, and "man" usually equates to being lesbian. Ironically, being read as "man" jeopardizes the player's location as a viable football subject.

\section{Embodied Masculinity}

Corporeal displays of masculinity by women disturb the ordering of sex, gender and, incidentally, desire because masculinity in women has been inextrica- 
bly annexed to lesbianism, particularly in sport. In the sports arena, butch is used to belittle and devalue women and their achievements. She is the bogey-woman (Cahn, 1994) of sport, instilling fear and loathing. In this research, reference to butch is frequent. In addition, the women also mention tomboy and, more recently, I have become aware of the use of "geezer-bird" to describe women players. A brief analysis of these subject positions illuminates the disciplining of sex-genderdesire in football contexts.

\section{Female Masculinity_Butch and Manly}

During the interviews, many of the women talk about football's prevailing stereotype. Body size appears significant. Here Donna (age 30) makes explicit and implicit reference to a player's physical size. Her view is that women who play are understood by others to be "gay." This is further defined in relation to big: "I think you immediately get labeled just because you play football, just because you play you are gay and you've got to be, and you are this big butch hulking around." What this also suggests is that "proper"/"real" women-that is, heterosexual and nonbig women-do not play. In addition to "bigness," the body is also read in relation to body posture and gesture (Bartky, 1988)—-that is, "hulking."

It is interesting that butch does not appear in the research without being attached to lesbian sexuality. This strong association functions in a way Sally Munt (1998) describes as the "gospel of lesbianism, inevitably interpreted as the true revelation of female homosexuality. . . Explicitly and implicitly the butch stands for the lesbian in the Lesbian Imaginary" (p. 54). This monolithic image of lesbian experience suggests that masculinity in women represents authentic lesbian sexuality, which is wholly inaccurate.

Most players distance themselves from the figure of the butch, and this is reflected in the findings and demonstrated by this questionnaire response: "Playing a traditional male sport people stereotype and assume you are a butch lesbian, which clearly I am not.” During the interviews, Collette (age 32) talks about this further, as she describes her experiences of playing against other teams: "They want to show everyone that they are not butch dykes, they're girlie feminines who can also play football." This corporeal gendered strategy to combat the seemingly ubiquitous butch in football is used to turn the gaze away from any signals of potential masculinity and suggests that masculinity in women is in fact an "abject gender" (Halberstam, 1998). In addition, the move reflects regulation of the order woman-feminine-heterosexual that is the corollary of the operation of hegemonic heterosexuality, compulsory heterosexual femininity, lesbianphobia, and butchphobia. In other words, masculine style for women is an anathema because of dominant heterosexual femininity and the fear of lesbians and butch women.

It is the interview research that provides the most detailed accounts of how players are recognized as not looking like "real" or "proper" women. In relation to sex-gender, their bodies are not intelligible (Butler, 1993). They are understood as not only butch but also "man/male." For instance, here Laura (age 33) quotes remarks from male spectators: "Well, we don't think that number 9 on the other side's female" and "Have you had a sex test, are you sure that she's female?" This act of verbally challenging the player's corporeality serves to call into question the "naturalness" of the sexed body. The suggestion that the player take a sex test references a process that socially and discursively produces "sex." Sex tests exist 
in sport and are carried out on women but not on men. The stated intention is to prevent men from gaining an unfair advantage by competing in "women's events." The test was devised by the International Olympic Committee's Medical Commission in 1966 and represents a male medical definition of "womanhood" and what constitutes "woman." As such, some feminists question the motives behind the test. For example, Mariah Burton Nelson (1996) suggests "maybe the concern is not so much that men will masquerade as women, but that women will no longer masquerade as women" (p. 79).

The sex test is premised on a scientific notion that men and women are distinguishable via chromosomal difference and that this difference can be regulated. However, it is evident that human beings do not fall exclusively into two chromosomal categories (Cream, 1995; Hood-Williams, 1995). Therefore, sex tests represent a regulatory practice used to materialize "sex" and uphold the notion of sexual difference. The testing procedure marks "viable" subjects and erases other identifications and, as such, demonstrates the exclusionary means through which the sexed body and gender are produced (Butler, 1993). It is apparent that the takenfor-granted notion that women and men have to be distinguishable (Cream, 1995; Hood-Williams, 1995) is most evident within sporting contexts. In addition, there is the structural and discursive demarcation of sport as "women's sport" or "men's sport." Football in particular has been and continues to be defined as a "man's sport." In this way playing usually acts as a signifier of manliness for men and mostly functions to make obdurate the man-masculine-heterosexual order. In contrast, women's experiences of sex-gender-desire and playing as a "viable" subject are far more complex.

Here I argue that, through an engagement with female masculinity, the complexities reflect the compulsory ordering of woman-feminine-heterosexual and the (re)production of sexual differentiation. It is this ordering that operates at the core of sport's gendered power relations. (For further discussion and analysis of the footballing butch, see Caudwell, 1999.) The findings suggest that the discourses within football in England and Wales are mostly butchphobic. The women's accounts surrounding embodied masculinity are not wholly about the figure of the butch lesbian, however. Tomboy is referenced mostly as a past subject position, although some of the women do acknowledge it as a current identity.

\section{Female Masculinity_Tomboys and Geezer-Birds}

Tom has been used historically to depict "deviant" women. For example, prostitutes in the late 19th century and early 20th century were often referred to as toms. This relates to the arguments presented by Esther Newton (1991) that sexually active women are in effect marked as male and that this functions to discipline the compulsory order women-feminine-heterosexual. That said, tomboy does not always carry a "deviant" sexual connotation. This is because, as Rita Laporte (1971) highlights, tomboyishness tends to be consigned to girlhood, which presents less of a threat to patriarchal power.

Let us begin with the "tomboy." She is not as damned as the "sissy" boy, destined to become a more feminine homosexual, for females are not so important, and, anyway she will outgrow it. (cited in Blasius \& Phelan, 1997, p. 359) 
Sportswomen's reference to having been a tomboy and the later rejection of this form of masculinity raises certain points. Is it that some sportswomen conform to gender "logic" through fear of not being recognizable as woman and therefore force themselves uncomfortably into prescribed femininity? Halberstam (1998) considers this conscious rejection of masculinity and describes masculinity in this context as an "abject gender." In contrast, Butler (1993) places the body as central to the issue and discusses "abject bodies." These are bodies that do not comply with gender "ideals" and do not display gender inscription; therefore, they are bodies that are not identifiable as "woman." Both concepts are significant to a critique of the compulsory order woman-feminine-heterosexual and inform the following discussion.

Recent research with young women in England (Smith, 2001) identifies the use of "geezer-bird" as a way onlookers describe women who play football. Unlike the usual consigning of tomboy to childhood, geezer-bird seems to refer to young women. This linguistic marking of women players alludes to female masculinity. However, reference to "bird" dilutes the signification as wholly masculine. As a discursive practice deployed to regulate women's sex-genderdesire, it is not dissimilar to "ladette." Although gender norms are reconfigured through the appropriation of masculine style by "ladettes" and "geezer-birds," women are still identifiable and women-feminine-heterosexual continues to be ordered and regulated, since these women are usually recognized as (hetero)sexually available. In the final instance, somewhat assumed heterosexual desire ensures ladettes and geezer-birds receive less policing than tomboys, and this is apparent given that it is young women who, no longer tomboys, are ladettes and geezer-birds.

Clearly playing football affects what it means to be a boy/man, or a girl/ woman and transgressing football and gender boundaries is discernible. More specifically, (not) playing and (not) looking like a "woman" rouses comment and selfsurveillance. These responses from the questionnaire iterate this point.

Didn't get to play for a while as a teenager because I felt it wasn't right (I had to be a girl!).

Was not allowed to play at school and when I hit my teens I did not want to play because I wanted to be a "woman"!

When I was younger I stopped playing because I was called a tomboy, but now I don't care.

These quotes indicate how girls and young women negotiate their corporeal intelligibility and football participation. Another example of this is provided here: "When I was at college I used to play with the boys and because I was better than some of them they used to call me a man even though I am small and petite." I argue that negotiating the rules of gender in sporting contexts is influenced by the notions of "abject gender" and "abject bodies" and the process of "girling the girl" (Butler, 1993). Butler argues that the "girl" is produced through the expectation that she will embody specific ideals of femininity and is "compelled to 'cite' the norm in order to qualify and remain a viable subject." In this way, the symbolic power of "girling" is that it "governs the formation of corporeally enacted femininity” (p. 232). 
Being called a "girl" from the inception of existence is a way in which the girl becomes transitively "girled" over time. This interpellation need not take on an explicit or official form in order to be socially efficacious and formative in the gendering of the subject. (1999, p. 121)

"In the gendering of the subject," both sex and gender are performed, and it is the imposed ordering of sex and gender that materializes "girl" and, in addition, (re)produces gendered power relations.

The process of becoming culturally intelligible for girls and women relies on the compulsory ordering of woman-feminine-heterosexual. Butler (1999) identifies interpellation and performativity as having both productive and generative domains. In the second part of this article I consider generative domains, in the meantime I continue to demonstrate how sex-gender-desire are produced in footballing contexts. An analysis of recent sports media coverage of women who play football demonstrates both interpellation and performativity in relation to the articulation and materialization of woman-feminine-heterosexual.

There is evidence that the increasing popularity and commercialization of the game affects the transmitted images of players. For example, the figure used as the Women's World Cup 1999 logo included a ponytail to signify femininity (Cox \& Thompson, 2000). More specifically Football Focus, BBC1's Saturday morning football coverage, ran a feature entitled "England's Angels" (November 25, 2000). Three of England's players (Katie Chapman, Rachel Yankey, and Marienne Spacey) attended a media-staged photo-shoot before an international fixture against Ukraine. The feature, a spoof of Charlie's Angels, promoted the successful qualification by England for the European Championships. Almost immediately a player (Katie Chapman) alludes to the sex-gender-desire imperative:

It is very nice, I mean for people to see us like a lady as well. . . I mean a lot of names are said about women that play football, but it's proven a point really that they can look like ladies and play football.

Although this is somewhat coded, I argue that the player offers a particular articulation and symbolic representation of footballer. This representation indicates the rules of sport's gender game, and it also highlights Bordo's (1993) point:

The rules of femininity have come to be culturally transmitted more and more through standardised visual images. ... We are no longer given verbal descriptions or exemplars of what a lady is or what femininity consists. Rather, we learn the rules directly through body discourse: through images that tell us what clothes, body shape, facial expression, movements, and behaviour are required. (cited in Conboy et al., 1997, p. 94)

The extract from the television program Football Focus demonstrates how, through articulation and materialization - that is, the formulation of body discourse - the "viable" footballing subject is "hailed" into social existence. The sports media reiterate the "norm" by representing the three women in particular ways. Their footballing bodies are produced to comply with the compulsory order of woman-feminine-heterosexual; they are recognizable as woman-feminine-heterosexual, even if they are not.

Within Butler's notion of performativity there are possibilities for resistance and challenges to the "norm" and "ideals." The refusal to comply with the woman- 
feminine-heterosexual imperative represents moments when women disobey body discourse and create new identities and orders. For example, Halberstam's (1998) celebration of "female masculinity" evidences a range of emerging butch identities and demonstrates the reclaiming of the normative order woman-masculinelesbian. By generating new sporting corporealities some women resist regulation and rearticulate the compulsory order woman-feminine-heterosexual.

\section{The Rearticulation of Sex, Gender, and Desire}

Butler (1998) argues that muscularity in women can function to challenge and transform gender ideals. More specifically, Martina Navratilova has been cited as an athlete who has "effectively unsettle[d] the rigidity of gendered expectations and broaden[ed] the scope of acceptable gender performance" (Butler, 1998, p. 5). Indeed, some 20 years later there is a new generation of muscular tennis players, for example, Venus Williams, Serena Williams, and Amelie Mauresmo. Such sporting corporealities reflect resistance to heterosexual femininity and bodily discourses of heterofemininity. The rearticulation of gender does not rely wholly on muscularity and the materialization of the contoured sporting body, although clearly body size and shape are significant to any discussion on shifting gender "norms" and "ideals." As Butler (1998) highlights,

Women's sports have the power to rearticulate gender ideals such that those very athletic women's bodies that, at one time, are considered outside the norm (too much, too masculine, even monstrous), can come, over time, to constitute a new ideal of accomplishment ... . ideals are not static, but constitute norms or standards that are surpassable and revisable. (p. 1)

In addition, it is important to consider other ways women challenge and resist the imposed ordering of woman-feminine-heterosexual. For example, it is possible to consider the presence of female masculinity as a representation of the rearticulation of the sexed body and gender. To be sure, Halberstam's (1998) thesis on "female masculinity" demonstrates the authenticity of the butch body and provides evidence that the signification "woman" can be disrupted and dislocated.

\section{Gendering the Self}

It is becoming more apparent that we are able to gender the self. For instance, accompanying the queer movement is the celebration of gender bending, gender variance, and gender diversity, as well as the plurality of sexuality. Queer subjects have publicly challenged hegemonic heterosexual notions of masculinity and femininity and resisted mutually exclusive and dimorphic gender norms. Such achievements are rare in the sporting arena and, although only a few of the women interviewed talked about their gendered body explicitly, it is important to identify sporting moments when gender "ideals" are disturbed and resisted.

\section{Adult Tomboy: Lesbian Gender and Heterosexual Identity}

As I have mentioned, many of the women in the research describe themselves during childhood as tomboys. It is also apparent that many drop the identity or depart from being read as tomboy when they enter adolescence. However, some 
of the women interviewed continued to describe themselves as tomboy. For example, Di (age 29, identifies as lesbian) states that she has "been a tomboy, always have been always will be, I'm a working-class tomboy." Similarly, Shirley (age 33, identifies as heterosexual) admits that she would still "definitely describe [her]self as a tomboy." Football is often cited as the reason that women recognize themselves and others as tomboy. For example, Collette (age 32, identifies as heterosexual) remembers being told, "I was a tomboy because I started to play."

When Di (age 29, identifies as lesbian) and also Tamsin (age 29, identifies as dyke) discuss being boyish, they include reference to their sexuality. For example, whilst talking about being a tomboy, Di mentions "declaring my love to a girl when I was 5-that I would marry her." More explicitly, Tamsin relates her sexuality to [tom]boyishness, when asked if she could describe a dyke:

Yes a dyke would probably be sort of quite boyish — tomboyish, short hair, you know drinking, sorted, likes a laugh. Someone like myself, someone who's cute [laughs].

In contrast, Kaz (age 31, identifies as gay) does not connect tomboyishness with her sexuality, although she continues to link football and tomboyishness, as is demonstrated here:

J: You talked about being a tomboy when you were younger.

$\mathrm{K}$ : Yeah.

$\mathrm{J}$ : Does the idea of being a tomboy tie in with your sexuality at all?

$\mathrm{K}$ : Em, no, I don't think so, because I've got friends who are straight who are tomboys, you know, so I don't think so, I think that just encouraged me to do the activities I did, like kick the can ${ }^{1}$ and football and make go-carts.

In relation to lesbian gender, it is evident that Di and Kaz recognize their past and present boyishness and that Tamsin explicitly adopts a masculine lesbian style. Interestingly, Tamsin distances herself from the figure of the butch, eventually identifying as "camp," usually a gay man's "masculine" style. In fact, none of the women interviewed came out as butch, implicitly raising issues surrounding how the butch lesbian body is largely pathologized and abhorred in sporting contexts.

As I have begun to argue, female sporting masculinity exists beyond lesbian gender, and Shirley's experiences illustrate the complexities of female masculinity, as well as highlighting heterosexual resistance to hegemonic femininity through a refusal to comply with gender "norms" and "ideals."

When I was younger, as a teenager, I looked very boyish and whatever ... and I think that not only did they assume sometimes that I was a boy, I would often get called "sonny." When they realized you was a woman, they assumed that you might be gay, because you look boyish. I think in the end my boyfriend was more embarrassed by that, you know we'd go somewhere and they'd say, "Come in lads." As you get older, perhaps a wedding ring, and with kids, it just don't become an issue any more. I would still describe myself as a tomboy and I don't have any problem with that. I mean I got called a man this morning and I just laughed. ... It's not a problem. 
Here Kaz makes further reference to heterosexual female masculinity when she describes a teammate:

$\mathrm{K}$ : She was the most heterosexual dyke I've ever seen. She was quite butch.

$\mathrm{J}$ : What do you mean by butch?

$\mathrm{K}$ : Short hair, quite muscular.

$\mathrm{J}$ : But heterosexual?

K: Yeah.

Both lesbian gender (in this research apparent as boyish) and heterosexual female masculinity, as articulations of corporeal gender motif, destabilize the compulsory order of woman-feminine-heterosexual. It is in these moments when players disobey the gender-sexual rules and offer rearticulations that possibilities open up for new identities; therefore, re-materializing gender and its relation to desire. For example, it is evident that new sex-gender-desire orders emerge from the research such as woman-boyish-lesbian, ${ }^{2}$ woman-boyish-heterosexual, and womanmasculine/butch-heterosexual. At this stage it is also clear that further research is required to explore more fully the ways women players disturb, challenge, and resist the compulsory order woman-feminine-heterosexual.

\section{Sexing Others}

If we accept that women's footballing bodies are formulated through footballing discourses that discipline and regulate the articulation of sex-genderdesire, then bodies that do not cite the imperative and are read "incorrectly" offer sites/sights of resistance. In other words, given that we understand the sex-gender rules, providing a body text that is not recognized as "woman" demonstrates a rearticulation of body discourse. This final discussion focuses on mistaken identity or, more specifically, the process of sexing others. I argue that recognizing the sexed body relies on an understanding of the sex-gender rules and that refusal to provide a body text that complies with the rules is significant. I suggest that, by providing a body text that is not read as "woman," players are disturbing and dislocating the sexed body binary and woman-feminine-heterosexual peremptory.

It is widely accepted that there are (socially constructed) gender clues that signify the sexed body. "Ideal" body size in relation to muscularity is one such signifier. From the research with footballers, body hair also emerges as a signifier of sex. Hair is viewed as a critical aspect of femininity and therefore a crucial indicator of sex. Bartky (1988, cited in Conboy, 1997) highlights how "a woman's skin must be soft, supple, hairless, and smooth. . . . Hair must be removed not only from the face but from large surfaces of the body as well, from legs and thighs" (p. 136). The nonremoval of hair disturbs the citation of corporeal femininity and impacts on the formulation of the sexed body and the sex-gender relation. In other words, within a system of dimorphic sex, the sexed body is legible as "woman" if it is hairless; otherwise the body is read as "man." This is demonstrated here when Sam (aged 28) talks about her early experiences of playing.

The women I first knew as a 14 year old were very strong physically, these were big tough women, at one point when I walked into the changing room, 
I thought I'd walked into a man's football team, because everyone had hair, everyone didn't shave their armpits, everyone didn't shave their legs.

Not only were the women Sam played with "big" and "tough," they also displayed hairy bodies. Sam's reading of hairiness demonstrates the social and discursive practices that produce sexed bodies. In addition to sex, it is usual that footballing bodies like these are also read in relation to desire (sexuality). Tamsin provides an explicit example of this: "I know for a fact that when I was thinking of joining United someone said 'Oh my god you don't want to join them-they're all big butch hairy lesbians." Such a comment demonstrates the discursive coupling of sex-gender-desire and the construction of normative orders such as womanmasculine/mannish-lesbian.

It is evident that a hairy body can have similar effects to a contoured body in that it dislocates the compulsory woman-feminine-heterosexual order and destabilizes the binary of sexed bodies. Body hair appears as a quantifiable indicator of sex, too much and too little function to inform sex. In relation to lesbian dyke and heterosexual dyke (discussed earlier), not having hair in a football context can function as resistance to sex-gender “ideals." Here is one of Kaz's early memories of football:

I remember City playing on Hackney Marshes. I remember thinking men and women do play football when they're older together, but it wasn't. It was two women's teams. I must have been about 12 . Some looked like men . . . had their hair cut short.

As with Sam's memory, Kaz recognizes and identifies the women players as "men." Evidently, in football contexts such as the changing room and on the field of play, and through the corporeal, some players successfully disobey the sex-gender-desire rules and resist the idea of sexual differentiation. They offer bodies that refuse to comply, and it is in these moments of mistaken sex identity that the sexed body is rearticulated.

\section{Concluding Remarks}

In the field of sports sociology, feminists have tended to focus mostly on the social construction of gender, with sexuality receiving some scrutiny (Clarke \& Humberstone, 1997; Hall, 1996; Hargreaves, 1994; Scraton \& Flintoff, 2002). To date little attention has been paid to the sex-gender-desire arrangement and its relation to sexual differentiation. In many ways this is hardly surprising, because sport of all cultural and social practices epitomizes sexual differentiation. In fact, most sport is premised on dimorphic sex and the notion that sex difference is "natural," stable, and fixed. It is this acceptance of sex as pregiven and prediscursive that continues to uphold the notion of the sex/gender distinction. In this article, I problematize the idea that sex is "natural" and prediscursive. I argue that, like gender and sexuality, it is regulated and formulated in order to propel a system that operates to make legitimate, and exclude, particular sporting bodies.

Through a focus on football and a critique of practices that function to formulate sex-gender-desire, I demonstrate how players negotiate their corporeality within heterosexual hegemony. It is evident that regulatory practices attempt to materialize women's sporting bodies through a compulsory ordering of woman- 
feminine-heterosexual. This ordering supports a system of sexual differentiation that attempts to foreclose rearticulations of sex-gender-desire and the sexed body. However, the above analysis also importantly exposes challenges and resistance to the sex-gender-desire imperative and identifies identities that destabilize sexual differentiation. For instance, it is evident that football provides the possibility for new identities via self-gendering and sexing others. That said, further research is needed that concentrates on the embodiment of sex-gender-desire to develop this argument more fully.

In all, the above discussions seek to open the way for a feminist-queer analysis of sporting corporealities. More specifically, the account offers a feminist critique of sport's system of sexual differentiation. Sex, gender, and desire are identified as inter-related and socially/culturally produced and re-produced. Butler's notion of performativity is used to understand the productive and generative effects of power's operation in this process. It is this application of existing feminist concepts and theory to sex, gender, desire, and sporting bodies that open the way for future research. More specifically, research that explores the possibilities footballing bodies offer for the production of new sex, gender, desire identities.

\section{References}

Bartky, S.L. (1988). Foucault, femininity, and the modernization of patriarchal power. In I. Diamond \& L. Quinby (Eds.), Feminism and Foucault: Reflections on resistance. Boston: Northern University Press.

Birrell, S., \& Cole, C. (1990) Double fault: Renee Richards and the construction and naturalization of difference. Sociology of Sport Journal, 7, 1-21.

Blasius, M., \& Phelan, S. (Eds.). (1997). We are everywhere. A historical sourcebook of gay and lesbian politics. London: Routledge.

Bordo, S. (1993). Unbearable weight: Feminism, western culture, and the body. Los Angeles \& Berkley: University of California Press.

Burton Nelson, M. (1996). The stronger women get, the more men love football: Sexism and the culture of sport. London: The Women's Press.

Butler, J. (1990). Gender trouble. Feminism and the subversion of identity. London: Routledge.

Butler, J. (1993). Bodies that matter. On the discursive limits of sex. London: Routledge.

Butler, J. (1998). Athletic genders: Hyperbolic instance and/or the overcoming of sexual binarism. Stanford Humanities Review, 6, 103-111.

Butler, J. (1999). Performativity's social magic. In R. Shusterman (Ed.), Bourdieu. A critical reader (pp. 113-128). London: Blakewell.

Cahn, S. (1994). Coming on strong. Gender and sexuality in twentieth-century women's sport. London: Harvard University Press.

Caudwell, J. (1999). Women's football in the United Kingdom: Theorising gender and unpacking the butch lesbian image. Journal of Sport and Social Issues, 23, 390-402.

Caudwell, J. (2002). Women's experiences of sexuality within football contexts: A particular and located footballing epistemology. Football Studies, 5, 24-45.

Clarke, G. (1997). Playing a part: The lives of lesbian physical education teachers. In G. Clarke \& B. Humberstone (Eds.), Researching women and sport (pp. 36-49). London: Macmillan.

Clarke, G, \& Humberstone, B. (Eds.). (1997). Researching women and sport. London: Macmillan. 
Conboy, K., Medina, N., \& Stanbury, S. (Eds.). (1997). Writing on the body. Female embodiment and feminist theory. New York: Columbia University Press.

Cox, B., \& Thompson, S. (2000). Multiple bodies-Sportswomen, soccer and sexuality. International Review for the Sociology of Sport, 35, 5-20.

Cream, J. (1995). Re-solving riddles: The sexed body. In D. Bell \& G. Valentine (Eds.), Mapping desire (pp. 31-40). London: Routledge.

Foucault, M. (1975/1991). Discipline and punish. The birth of the prison. London: Penguin.

Gatens, M. (1992). Power, bodies and difference. In M. Barrett \& A. Phillips (Eds.), Destabilising theory (pp. 120-137). Cambridge: Polity Press.

Grosz, E. (1994). Bodies and knowledge: Feminism and crisis of reason. In L. Alcoff \& E. Potter (Eds.), Feminist epistemologies (pp. 187-215). London: Routledge.

Halberstam, J. (1998). Female masculinity. London: Duke University Press.

Hall, M.A. (1996) Feminism and sporting bodies. Leeds: Human Kinetics.

Hargreaves, J. (1994). Sporting females. Critical issues in the history and sociology of women's sports. London: Routledge.

Hood-Williams, J. (1995). Sexing athletes. Sociology of Sport Journal, 12, 290-305.

Kelly, L., Burton, S., \& Regan, L. (1994). Researching women's lives or studying women's oppression? Reflections on what constitutes feminist research. In M. Maynard \& J. Purvis (Eds.), Researching women's lives from a feminist perspective (pp. 27-48) London: Taylor \& Francis.

Laporte, R. (1971). The butch/femme question. In M. Blasius \& S. Phelan (Eds., 1997), We are everywhere. A historical sourcebook of gay and lesbian politics (pp. 355-364). London: Routledge.

McNay, L. (1992). Foucault and feminism. Cambridge: Polity.

Munt, S. (1998). Heroic desire: Lesbian identity and cultural space. London: Cassell.

Newton, E. (1991). The mythic mannish lesbian: Radclyffe Hall and the new woman. London: Penguin.

Reinharz, S. (1983). Experiential analysis: A contribution to feminist research. In G. Bowles \& R. Klein (Eds.), Theories of women's studies (pp. 162-191). London: Routledge \& Kegan Paul.

Scraton, S., \& Flintoff, A. (2002). Gender and sexuality: A reader. London: Routledge.

Shilling, C. (1993). The body and social theory. London: Sage.

Smith, K. (2001). A study of homophobia in women's football. Unpublished undergraduate thesis, Leeds Metropolitan University.

Wittig, M. (1981). One is not born a woman. Feminist Issues, 1, 47-54.

\section{Notes}

${ }^{1}$ A game that is based on hide and seek with the possibility to release those who have been found by kicking a can and restarting the hide and seek process.

'I am also aware that some women are describing themselves as "lesbian-boi." 